\title{
Keragaman Plankton dan Kondisi Perairan Tambak Intensif dan Tradisional di Probolinggo Jawa Timur
}

\author{
Utojo \\ Balai Penelitian dan Pengembangan Budidaya Air Payau \\ Jl. Makmur Dg Sitakka No. 129 Maros 90512, Sulawesi Selatan \\ E mail: utojorivai@gmail.com
}

\begin{abstract}
This study aims to estimate the wealth and stability of traditional and intensive brackishwater pond waters through biological index calculation (diversity, uniformity and dominance of plankton) in traditional and intensive brackishwater pond waters of Probolinggo Regency, East Java Province. Sampling plankton and water from the site, considered to represent the diversity of plankton and water stability of traditional and intensive brackishwater pond. Plankton was collected using a plankton net no. 25, then preserved using $1 \%$ lugol solution. Measurement of water quality variables include temperature, salinity, dissolved oxygen and $\mathrm{pH}$, whereas the laboratory analyzes that Total Organic Matter (TOM), $\mathrm{NO}_{2}, \mathrm{NO}_{3}$, $\mathrm{NH}_{3}, \mathrm{PO}_{4}$, Total Suspended Solids (TSS), and Fe. Plankton identification using microscope and calculation with cell counting method. The results of analysis of plankton in intensive brackishwater pond waters are obtained as much as 23 genera consisting of 16 genera of phytoplankton were included into three classes, namely Bacillariophyceae as much as 5 genera, Cyanophyceae 3 genera, Dinophyceae and Chlorophyceae, each of the four genera, whereas zooplankton consisting of 7 genera are included into two classes, namely Crustaceae 6 genera and Rotatoria 1 genus. In traditional brackishwater pond earned as much as 13 genera consisting of 8 genera of phytoplankton were included into Bacillariophyceae 5 genera, Cyanophyceae 2 genera, and Dinophyceae 3 genera, whereas zooplankton consisting of three genera are included into class Crustaceae 2 genera and Rotatoria 1 genus. Plankton abundance in intensive brackishwater pond ranges $702-4269$ ind./L, diversity index of $0.26-2.38$, uniformity index of $0.10-1.5$, and dominance index of $0.02-0.68$. In traditional brackishwater pond have an abundance of plankton range $134-776$ ind./L, diversity index of $0.10-1.97$, uniformity index of 0.08 1.0 , and dominance index of $0.01-0.75$. Traditional and intensive brackishwater pond waters condition still within the limits that can be tolerated by the culture organism. Based on the index value of biological, diversity of genus in the intensive brackishwater pond is relatively higher than traditional brackishwater pond and the community stability moderate, whereas traditional brackishwater pond unstable. On average, the uniformity of the genus in both brackishwater ponds are relatively evenly and genus of plankton to dominate the others genus.
\end{abstract}

Keywords: diversity of plankton, waters condition, traditional and intensive brackishwater pond, Probolinggo Regency

\begin{abstract}
Abstrak
Studi ini bertujuan untuk mengestimasi kekayaan dan kestabilan perairan tambak intensif dan tradisional melalui perhitungan indeks biologi (keragaman, keseragaman dan dominansi plankton) di perairan tambak intensif dan tradisional Kabupaten Probolinggo, Provinsi Jawa Timur. Pengambilan contoh plankton dan air dari lokasi, dianggap merepresentasikan keragaman plankton dan stabilitas perairan tambak intensif dan tradisional. Plankton dikoleksi menggunakan plankton net no. 25, kemudian diawetkan menggunakan larutan lugol 1\%. Pengukuran peubah kualitas air tambak antara lain suhu, salinitas, oksigen terlarut dan $\mathrm{pH}$, sedangkan yang dianalisis di laboratorium yaitu Bahan Organik Total (BOT), $\mathrm{NO}_{2}, \mathrm{NO}_{3}, \mathrm{NH}_{3}, \mathrm{PO}_{4}$, Padatan Tersuspensi Total, dan Fe. Identifikasi plankton menggunakan mikroskop dan perhitungannya dengan metode counting cell. Hasil studi analisis plankton diperairan tambak intensif didapatkan sebanyak 23 genera yang terdiri dari 16 genera fitoplankton yang tercakup ke dalam 3 kelas, yaitu Bacillariophyceae sebanyak 5 genera, Cyanophyceae 3 genera, Dinophyceae dan Chlorophyceae, masing-masing 4 genera, sedangkan zooplankton terdiri dari 7 genera yang tercakup ke dalam 2 kelas yaitu Crustaceae sebanyak 6 genera dan Rotatoria 1 genus. Di tambak tradisional didapatkan sebanyak 13 genera yang terdiri dari 8 genera fitoplankton yang tercakup ke dalam Bacillariophyceae sebanyak 5 genera, Cyanophyceae 2 genera, dan Dinophyceae 3 genera, sedangkan zooplankton terdiri dari 3 genera yang tercakup ke dalam kelas Crustaceae sebanyak 2 genera dan Rotatoria 1 genus. Kelimpahan plankton di tambak intensif berkisar 702 - 4269 ind./L, indeks keragaman
\end{abstract}


$0,26-2,38$, keseragaman $0,10-1,5$, dan dominansi $0,02-0,68$, serta di tambak tradisional memiliki kelimpahan plankton berkisar 134 - 776 ind./L, indeks keragaman 0,10 - 1,97, keseragaman 0,08 - 1,0, dan dominansi $0,01-0,75$. Kondisi perairan tambak intensif dan tradisional masih dalam batas yang dapat ditolerir oleh organisme budidaya. Berdasarkan nilai indeks biologi, keragaman genus di tambak intensif relatif lebih tinggi dari pada tambak tradisional dan stabilitas komunitasnya moderat, sedangkan tambak tradisional tidak stabil. Secara rata-rata, keseragaman genus di kedua tambak tersebut relatif merata dan genus plankton mendominasi genus yang lain.

Kata kunci: keragaman plankton, kondisi perairan, tambak intensif dan tradisional, Kabupaten Probolinggo

\section{Pendahuluan}

Pemanfaatan kawasan pesisir untuk usaha budidaya tambak udang, diharapkan dapat memberikan kontribusi yang sangat besar terhadap peningkatan kesejahteraan masyarakat pembudidaya, pendapatan pemerintah daerah dan perolehan devisa negara.

Usaha budidaya tambak di Kabupaten Probolinggo saat ini tersebar di 7 kecamatan pesisir yaitu Kecamatan Tongas, Dringu, Sumberasih, Gending, Pajarakan, Kraksaan, dan Paiton. Di setiap wilayah kecamatan tersebut terdapat kegiatan budidaya tambak udang windu atau bandeng tradisional yang dikelola oleh masyarakat baik secara monokultur maupun polikultur. Pengusaha tambak yang membudidayakan udang vaname intensif antara lain di Kecamatan Tongas, Gending, dan Pajarakan (Anonim, 2012).

Menurut Poernomo (1988), manfaat plankton pada pengelolaan tambak udang intensif yaitu saat kekeruhan karena plankton dengan nilai daya cerah perairan antara $30-40 \mathrm{~cm}$ justru diperlukan dan pertumbuhan plankton yang baik ditandai oleh berubahnya warna air tambak dari coklat muda hingga hijau daun muda, mutlak dipertahankan karena: 1) plankton membuat tambak menjadi teduh, sehingga udang dapat lebih aktif mencari makan di siang hari; 2) plankton nabati merupakan produsen $\mathrm{O}_{2}$ dalam air; 3) bermanfaat sebagai pakan alami udang khususnya pada awal pemeliharaan setelah penebaran benur; 4) menekan pertumbuhan klekap dan lumut di dasar tambak; dan 5) plankton nabati membantu menyerap senyawa yang sangat berbahaya bagi udang seperti ammonia, nitrit dan nitrat. Masalah yang dihadapi dalam pengelolaan tambak udang intensif yang ditandai dengan menurunnya daya cerah perairan dan seringnya terjadi blooming plankton terutama karena semakin suburnya dasar tambak akibat timbunan suspensi organik dari kotoran udang dan sisa-sisa pakan (pelet), menumpuknya sel plankton yang sudah tua dan mati serta gerakan udang yang aktif karena semakin besar.

Pada pengelolaan tambak udang tradisional, mutlak menggunakan plankton (fitoplankton dan zooplankton) sebagai sumber utama pakan alaminya yang harus dikembangkan dan dipertahankan melalui pemupukan dasar (awal) saat persiapan yaitu pupuk organik $400-1.000 \mathrm{~kg} / \mathrm{ha}$, urea $200-400$ kg/ha, dan SP-36 $100-200 \mathrm{~kg} / \mathrm{ha}$. Untuk mempertahankan agar warna air tambak karena plankton selalu mendekati warna hijau kecoklatan (warna air tambak yang baik untuk budidaya udang), saat pelaksanaan budidaya dilakukan pemupukan susulan yaitu urea dan SP-36 sekitar $10 \%$ dari pupuk dasar, sehingga keberhasilan usaha tambak udang tradisional, banyak tergantung pada tersedianya plankton (Atmomarsono et al., 2011).

Kepadatan plankton yang berlebihan dalam perairan tambak, berbahaya bagi udang yang dibudidayakan karena: 1) saat cuaca cerah akan terjadi produksi $\mathrm{O}_{2}$ yang berlebihan melalui proses fotosintesis. Kadar $\mathrm{O}_{2}$ yang mencapai kejenuhan $250 \%$ menimbulkan gas emboli pada jaringan daun insang udang. Karena gangguan akut pernafasan, udang biasanya mengambang di permukaan air tambak. Sebaliknya saat malam hari, akan terjadi kekurangan $\mathrm{O}_{2}$ karena proses respirasi oleh plankton. Persyaratan mutu air bagi tambak udang memiliki oksigen terlarut berkisar 3-10 mg/L (Poernomo, 1988).

Mekanisme rantai makanan di dalam perairan budidaya tambak udang tradisional yaitu bersumber dari fitoplankton (plankton yang bersifat nabati) yang posisinya sebagai 
produsen primer dari zooplankton (plankton yang bersifat hewani) dan selanjutnya dimakan ikan dan udang. Suatu perairan tambak dikatakan subur apabila di dalamnya banyak produsen primer yaitu fitoplankton, baik kuantitas maupun kualitasnya sebagai sumber pakan alami dan juga berperan sebagai penghasil oksigen melalui proses fotosintesis (Setyobudiandi et al., 2009).

Menurut Barnes dan Mann (1991), tingkat produksi plankton di suatu perairan dapat digunakan untuk menduga potensi produksi udang dan ikan, kondisi suatu perairan bersifat stabil atau tidak stabil dan apabila populasi plankton di suatu perairan lewat jenuh (blooming) dapat dijadikan sebagai indikator pencemaran biologis.

Ekosistem suatu perairan dengan keragaman hayati yang rendah adalah tidak stabil dan rentan terhadap pengaruh tekanan dari luar dibandingkan dengan ekosistem yang memiliki keragaman hayati yang tinggi (Boyd, 1990).

Kondisi lingkungan perairan tambak yang stabil ditandai dengan keragaman plankton tinggi, jumlah individu setiap spesies tinggi dan merata serta kualitas air lingkungan tambak berada dalam kisaran yang sesuai dengan pertumbuhan organisme budidaya. Tujuan penelitian untuk mengestimasi kekayaan dan kestabilan perairan melalui perhitungan indeks biologi (keragaman, keseragaman dan dominansi plankton) di tambak intensif dan tradisional Kabupaten Probolinggo, Provinsi Jawa Timur.

Indeks Keragaman Jenis:

$$
\begin{gathered}
\mathrm{H}^{\prime}=-\underset{\mathrm{ni}}{\mathrm{pi}} \ln \mathrm{pi} \\
\mathrm{pi}=-\mathrm{N}
\end{gathered}
$$

Keterangan :

Indeks Keseragaman:

$$
E=\frac{H^{\prime}}{H^{\prime} \text { maks }}
$$

Keterangan :

Indeks Dominansi:

$$
D=(p i)^{2}
$$

Keterangan :

$E=$ Indeks keseragaman jenis

$\mathrm{H}^{\prime}=$ Indeks keragaman jenis

$\mathrm{H}^{\prime}$ maks = Indeks keragaman maksimum

$$
\begin{aligned}
& \mathrm{D}=\text { Indeks dominansi } \\
& \mathrm{ni}=\text { Jumlah individu taksa ke-i } \\
& \mathrm{N}=\text { Jumlah total individu } \\
& \mathrm{pi}=\text { ni/N = Proporsi spesies ke- } \mathrm{i}
\end{aligned}
$$

\section{Materi dan Metode}

tambak intensif dan tradisional di tuju kecamatan pesisir Kabupaten Probolinggo, Provinsi Jawa Timur. Titik-titik stasiun pengamatan ditetapkan posisinya menggunakan alat bantu GPS (Global Positioning System), ditentukan secara random dan sebarannya dapat dilihat pada Gambar 1. Di setiap stasiun, contoh plankton dan air diambil pada tambak yang sedang dalam masa pemeliharaan. Plankton menyaring air sebanyak $1 \%$. Peubah kualitas tambak meliputi suhu, $\mathrm{pH}$, salinitas, dan oksigen terlarut, sedangkan nitrat, nitrit, amonia, fosfat, bahan organik total, dan tersuspensi total dianalisis di Identifikasi jenis plankton dilakukan di giknakan mikroskop yang (1977), Yamaji (1976), dan dan Newell serta kelimpahannya menggunakan 2005). Untuk mengetahui kekayaan dan kestabilan perairan, maka dilakukan analisis kuantitatif indeks biologi plankton meliputi perhitungan keragaman, keseragaman, dan dominansi dari Shannon-Wiener (Odum, 1971; Basmi, 2000) dan formulanya sebagai berikut:

$\mathrm{H}^{\prime}=$ Indeks keragaman jenis

$\mathrm{N}=$ Jumlah total individu

$\mathrm{pi}=\mathrm{ni} / \mathrm{N}=$ Proporsi spesies ke-i 


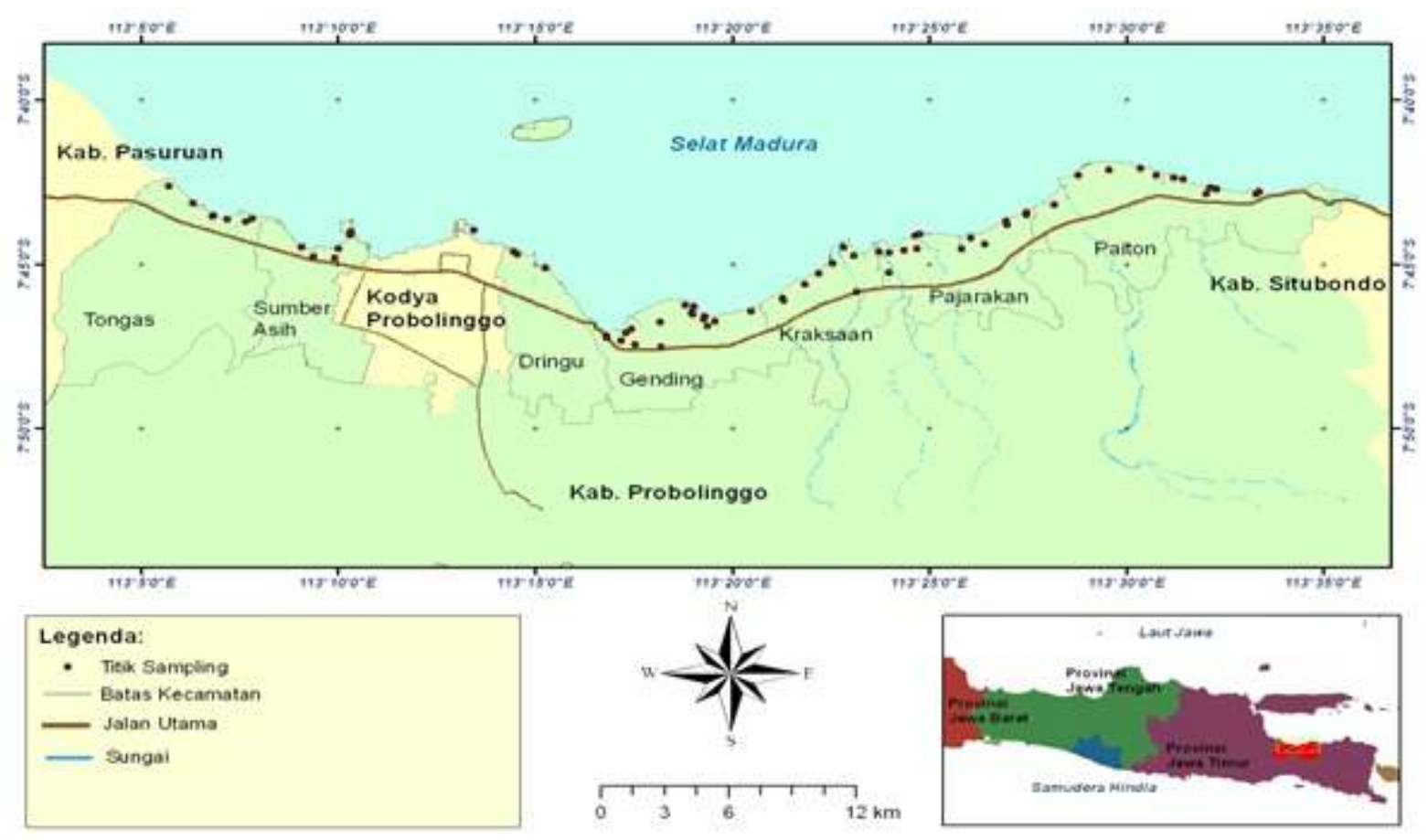

Gambar 1. Peta sebaran titik sampling plankton di kawasan tambak Kabupaten robolinggo, Provinsi Jawa Timur

Kualitas air yang diukur terdiri dari peubah fisika dan kimia yang dianggap berpengaruh terhadap keragaman plankton seperti disajikan pada Tabel 1. Contoh air diambil dari lokasi yang dianggap merepresentasikan kondisi lingkungan perairan tambak dan metode analisisnya berpedoman pada Haryadi et al. (1992) dan
APHA (1998). Statistik deskriptif digunakan untuk mengetahui gambaran umum (minimum, maksimum, rata-rata dan simpangan baku) dari kelimpahan, jumlah genus dan indeks biologi (keragaman, keseragaman dan dominansi) plankton serta kondisi lingkungan perairan tambak.

Tabel 1. Peubah kualitas air yang diamati di tambak intensif dan tradisional Kabupaten Probolinggo, Provinsi Jawa Timur

\begin{tabular}{|c|c|c|}
\hline Peubah & Alat/metode & $\begin{array}{c}\text { Analisis } \\
\text { laboratorium/lapangan }\end{array}$ \\
\hline $\begin{array}{l}\text { Fisika } \\
\text { Suhu }\left({ }^{\circ} \mathrm{C}\right)\end{array}$ & DO-meter & Lapangan \\
\hline Kimia & DO-meter & Lapangan \\
\hline Oksigen terlarut (mg/L) & Hand refraktometer & Lapangan \\
\hline $\begin{array}{l}\text { Salinitas (ppt) } \\
\text { pH }\end{array}$ & pH-meter & Lapangan \\
\hline Padatan tersuspensi total & Gravimetrik & Lapangan \\
\hline$(\mathrm{mg} / \mathrm{L})$ & Botol sampel, spectrophotometer & Laboratorium \\
\hline $\mathrm{NO}_{2}(\mathrm{mg} / \mathrm{L})$ & Botol sampel, reduksi cadmium & Laboratorium \\
\hline $\mathrm{NO}_{3}(\mathrm{mg} / \mathrm{L})$ & Botol sampel, phenat & Laboratorium \\
\hline $\mathrm{NH}_{3}(\mathrm{mg} / \mathrm{L})$ & Botol sampel, asam askorbit & Laboratorium \\
\hline $\mathrm{PO}_{4}(\mathrm{mg} / \mathrm{L})$ & Botol sampel, phenantrolin & Laboratorium \\
\hline $\begin{array}{l}\mathrm{Fe}(\mathrm{mg} / \mathrm{L}) \\
\text { Bahan organik total (mg/L) }\end{array}$ & Titrimetrik & Laboratorium \\
\hline $\begin{array}{l}\text { Biologi } \\
\text { Plankton (fitoplankton dan } \\
\text { zooplankton) }\end{array}$ & $\begin{array}{l}\text { Plankton net ukuran } 60 \mu \text {, botol } \\
\text { sampel, preservatif, mikroskop }\end{array}$ & Laboratorium \\
\hline
\end{tabular}




\section{Hasil dan Pembahasan}

\section{A. Keragaman plankton}

Pada umumnya selain terjadi perubahan kelimpahan plankton di perairan tambak, juga disertai dengan perubahan genus plankton secara berfluktuatif sepanjang tahun. Hal ini disebabkan oleh faktor alam dan kegiatan manusia. Genus plankton (fitoplankton dan zooplankton) yang ditemukan pada studi ini ditampilkan pada Tabel 2 dan 3.

Hasil pengamatan plankton di perairan tambak intensif, teridentifikasi sebanyak 23 genera yang terdiri dari 16 genera fitoplankton yang tercakup ke dalam 3 kelas, yaitu Bacillariophyceae sebanyak 5 genera, Cyanophyceae 3 genera, Dinophyceae dan Chlorophyceae, masing-masing 4 genera, sedangkan zooplankton terdiri dari 7 genera yang tercakup ke dalam 2 kelas yaitu Crustaceae sebanyak 6 genera dan Rotatoria 1 genus.

Di tambak tradisional didapatkan sebanyak 13 genera yang terdiri dari 8 genera fitoplankton yang tercakup ke dalam Bacillariophyceae sebanyak 5 genera,
Cyanophyceae 2 genera, dan Dinophyceae 3 genera, sedangkan zooplankton terdiri dari 3 genera yang tercakup ke dalam kelas Crustaceae sebanyak 2 genera dan Rotatoria 1 genus. Plankton di tambak intensif ragamnya relatif lebih tinggi dibandingkan dengan tambak tradisional.

Plankton termasuk mikroorganisme yang hidupnya melayang-layang dalam air dan banyak sedikitnya komunitas plankton ditentukan oleh debet air yang masuk dari sumber air laut ke dalam tambak melalui frekuensi pergantian air. Hal ini dibuktikan dengan jumlah genus plankton di tambak intensif lebih banyak dari pada di tambak tradisional diduga karena frekuensi penggantian air baru pada tambak intensif saat pelaksanaan budidaya lebih sering dilakukan yaitu setiap tiga hari menggunakan pompa, sedangkan tambak tradisional penggantian air baru hanya dilakukan pada saat pasang tinggi yaitu setiap dua minggu, sehingga banyaknya jumlah genus plankton di tambak intensif ditentukan oleh seringkalinya pergantian air baru dari laut.

Tabel2. Genus, kelas, dan kelompok fitoplankton dan zooplankton yang didapatkan di perairan tambak intensif Kabupaten Probolinggo, Provinsi Jawa Timur

\begin{tabular}{|c|c|c|}
\hline Kelompok & Kelas & Genus \\
\hline \multirow[t]{4}{*}{ Fitoplankton } & Bacillariophyceae & $\begin{array}{l}\text { Melosira sp } \\
\text { Navicula sp } \\
\text { Nitzschia sp } \\
\text { Pleurosigma sp } \\
\text { Coscinodiscus sp }\end{array}$ \\
\hline & Cyanophyceae & $\begin{array}{l}\text { Oscillatoria sp } \\
\text { Gleocapsa sp } \\
\text { Merismopedia sp }\end{array}$ \\
\hline & Dinophyceae & $\begin{array}{l}\text { Prorocentrum sp } \\
\text { Gyrodinium sp } \\
\text { Protoperidinium sp } \\
\text { Signema sp }\end{array}$ \\
\hline & Chlorophyceae & $\begin{array}{l}\text { Tetrastrum sp } \\
\text { Ceratium } \mathrm{sp} \\
\text { Chaetoceros sp } \\
\text { Thallasionema sp }\end{array}$ \\
\hline \multirow[t]{2}{*}{ Zooplankton } & Crustaceae & $\begin{array}{l}\text { Apocyclops sp } \\
\text { Copepoda sp } \\
\text { Tortanus sp } \\
\text { Temora sp } \\
\text { Acartia sp } \\
\text { Oithona sp }\end{array}$ \\
\hline & Rotatoria & Brachionus sp \\
\hline
\end{tabular}


Menurut Klemeneie et al. (2007) bahwa faktor utama yang mempengaruhi struktur komunitas fitoplankton adalah perubahan kondisi lingkungan perairan pantai termasuk tambak yang disebabkan oleh pasang surut dan musim. Dalam studi ini, jumlah genus plankton relatif lebih tinggi di tambak intensif dan lebih rendah di tambak tradisional bila dibandingkan dengan hasil penelitian Utojo dan Pirzan (2009) yang didapatkan terdiri dari 15 genera fitoplankton dengan komposisi: kelas Bacillariophyceae terdapat 9 genera, kelas Chlorophyceae dan Cyanophyceae, masing-masing 1 genus serta Dinophyceae 2 genera, sedangkan zooplankton terdiri dari 2 genera.

Komposisi fitoplankton dalam studi ini, didominasi oleh kelas Bacillariophyceae, tampaknya sesuai dengan kebutuhan budidaya udang di tambak karena kelas ini merupakan pakan alami yang lebih disukai oleh udang dibandingkan dengan kelas lainnya (Gracia dan Gracia, 1985). Menurut Nontji (2008) bahwa komponen fitoplankton dari kelas Bacillariophyceae atau diatom ini bersifat kosmopolit, cepat berkembang di perairan dan paling umum dijumpai di laut, mulai dari wilayah pantai termasuk tambak hingga laut lepas.

Indikator tambak yang baik untuk budidaya udang yaitu airnya berwarna coklat muda karena pertumbuhan plankton yang didominasi oleh genus Navicula sp dan Nitzschia sp dari kelas Bacillariophyceae dan dengan kecerahan air $35 \mathrm{~cm}$ baik untuk dipertahankan (Poernomo, 1988). Komposisi zooplankton yang didapatkan pada tambak intensif dan tradisional didominasi oleh Crustaceae karena kelas ini merupakan plankton air laut yang memiliki toleransi tinggi terhadap perubahan kondisi lingkungan perairan, seringkali masuk ke dalam tambak saat pergantian air dan berkembang dalam tambak sebagai pakan alami hewani yang lebih disukai oleh udang.

Di perairan laut seringkali dijumpai kelas Crustaceae mendominasi komposisi zooplankton lainnya. Dominasi jenis zooplankton dari kelas Crustaceae ini juga ditemukan pada kawasan tambak budidaya udang yang sumber airnya langsung dari laut (Amin dan Suwoyo, 2012).

Tabel 3. Genus, kelas, dan kelompok plankton (fitoplankton dan zooplankton) yang didapatkan di perairan tambak tradisional Kabupaten Probolinggo

\begin{tabular}{ccc}
\hline Kelompok & Kelas & Genus \\
\hline Fitoplankton & Bacillariophyceae & Navicula $\mathrm{sp}$ \\
& & Coscinodiscus $\mathrm{sp}$ \\
Nitzschia $\mathrm{sp}$ \\
Pleurosigma $\mathrm{sp}$ \\
& Gleotrichia $\mathrm{sp}$ \\
& & Oscillatoria $\mathrm{sp}$ \\
& Cyanophyceae & Gleocapsa $\mathrm{sp}$ \\
& Dinophyceae & Prorocentrum $\mathrm{sp}$ \\
& & Gyrodinium $\mathrm{sp}$ \\
& & Protoperidinium $\mathrm{sp}$ \\
& Crustaceae & Tortanus $\mathrm{sp}$ \\
& & Oithona $\mathrm{sp}$ \\
& Rotatoria & Brachionus $\mathrm{sp}$
\end{tabular}

Kelimpahan genus plankton dalam perairan berfluktuatif bergantung pada musim, terdapat beberapa genus plankton yang melimpah pada musim kemarau, sedangkan genera lainnya melimpah pada musim hujan. Fluktuasi tersebut dipengaruhi oleh beberapa faktor, termasuk suhu, $\mathrm{pH}$, konsentrasi nutrien, cahaya, cuaca, penyakit, pemangsaan ikan dan zooplankton, kompetisi antara spesies, toksin alga (Boyd, 1990). Kelimpahan dan jumlah genus serta indeks biologi plankton ditampilkan pada (Tabel 4 dan 5; Lampiran 1 dan 2). 
Hasil pengamatan kelimpahan plankton di perairan tambak intensif berkisar 702 - 4269 ind./L, memiliki kisaran jumlah individu yang relatif lebih tinggi dibandingkan dengan jumlah individu di perairan tambak tradisional (134 - 776 ind./L). Pada tambak intensif, sistem irigasi airnya dilengkapi dengan saluran pemasukan dan pembuangan secara terpisah, desain, tataletak dan konstruksi tambaknya teratur dengan baik yang dapat meningkatkan kualitas air serta ditunjang oleh tersedianya nutrien dari sisa pakan udang terutama unsur $\mathrm{N}$ dan $\mathrm{P}$ anorganik, berdampak lebih mempercepat perkembangan jumlah individu plankton dibandingkan dengan tambak tradisional.

Kelimpahan plankton (tambak tradisional) pada studi ini relatif lebih rendah dibandingkan dengan tambak tradisional di Kabupaten Sinjai pada kisaran 140 - 2060 ind./L (Pirzan et al., 2003), di Kabupaten Bulukumba, Jeneponto, Maros, Pinrang dan Takalar, Provinsi Sulawesi Selatan pada kisaran 455 - 1475 ind./L (Pirzan dan PongMasak, 2007). Pada tambak intensif dan tradisional, terdapat beberapa genus yang memiliki jumlah individu lebih banyak dibandingkan dengan genus yang lain di antaranya Navicula sp dan Coscinodiscus sp dari Kelas Bacillariophyceae dan Oscillatoria sp dari Kelas Cyanophyceae.

Umumnya genera yang termasuk Kelas Bacillariophyceae bersifat kosmopolit dan cepat berkembang di perairan tambak serta Oscillatoria sp termasuk salah satu genus yang dapat beradaptasi dengan salinitas mencapai 90 ppt dan suhu mencapai $37^{\circ} \mathrm{C}$ (Pirzan dan Utojo, 2010). Hal ini sesuai dengan pengamatan Utojo dan Pirzan (2009) yang mengungkapkan bahwa hanya dari genus Oscillatoria $\mathrm{sp}$ yang ditemukan pada salinitas tinggi (> 100 ppt) di tambak bandeng dan garam Kabupaten Jeneponto. Jumlah genus yang ditemukan pada tambak intensif berkisar 6 - 14 genera dan pada tambak tradisional berkisar 3-10 genera (Tabel 4 dan 5; Lampiran 1 dan 2). Jumlah genus pada tambak tradisional relatif lebih rendah dibandingkan dengan tambak intensif seperti yang telah disebutkan terdahulu yaitu pada tambak tradisional, faktor frekuensi penggantian air tambak dilakukan setiap dua minggu hanya pada saat pasang tinggi, sedangkan penggantian air tambak intensif dilakukan setiap tiga hari menggunakan pompa, sehingga akan berpengaruh terhadap keragaman plankton. Jumlah genus pada tambak intensif dan tradisional yang ditemukan dalam studi ini relatif lebih tinggi dibandingkan dengan tambak tradisional di Kabupaten Mamuju dan Sinjai, masing-masing pada kisaran 2 7 dan 2 - 8 genera (Pirzan et al., 2003). Jumlah genus pada tambak tradisional dalam studi ini relatif lebih rendah dibandingkan dengan tambak tradisional di Kabupaten Bulukumba, Jeneponto, Maros, Pinrang dan Takalar, tetapi pada tambak intensif dalam studi ini relatif sama dibandingkan dengan di setiap kabupaten tersebut yaitu pada kisaran 8 - 14 genera (Pirzan dan Pong-Masak, 2007).

Tabel 4. Jumlah individu dan genus, keragaman, keseragaman, dominansi plankton setiap stasiun di kawasan tambak intensif Kabupaten Probolinggo

\begin{tabular}{lcccc}
\hline \multicolumn{1}{c}{ Parameter } & Minimum & Maksimal & Rata-rata & $\begin{array}{c}\text { Simpangan } \\
\text { Baku }\end{array}$ \\
\hline Jumlah individu (ind./L) & 702,0 & 4269,0 & 2140,14 & 2786,43 \\
Jumlah genus & 6,0 & 14,0 & 10,43 & 8,61 \\
Keragaman (H') & 1,26 & 2,38 & 1,87 & 1,45 \\
Keseragaman (E) & 0,10 & 1,5 & 0,76 & 0,30 \\
Dominansi (D) & 0,02 & 0,68 & 0,39 & 0,20 \\
\hline
\end{tabular}


Tabel 5. Jumlah individu dan genus, keragaman, keseragaman, dominansi plankton setiap stasiun di kawasan tambak tradisional Kabupaten Probolinggo, Provinsi Jawa Timur

\begin{tabular}{lcccc}
\hline \multicolumn{1}{c}{ Parameter } & Minimum & Maksimal & Rata-rata & Simpangan Baku \\
\hline Jumlah individu (ind./L) & 134,0 & 776,0 & 455,14 & 573,46 \\
Jumlah genus & 3,0 & 10,0 & 6,0 & 3,87 \\
Keragaman (H') & 0,10 & 1,97 & 0,97 & 0,51 \\
Keseragaman (E) & 0,08 & 1,0 & 0,78 & 0,23 \\
Dominansi (D) & 0,01 & 0,75 & 0,42 & 0,20 \\
\hline
\end{tabular}

Rendahnya jumlah genus pada tambak tradisional karena saat dilakukan studi ini bertepatan dengan musim kemarau dan kondisi tambaknya pada umumnya relatif dangkal, saat siang hari suhu airnya tinggi berkisar $35,3-37,2^{\circ} \mathrm{C}$ akan memacu laju evaporasi secara cepat menyebabkan salinitasnya juga tinggi yaitu 30 - 38 ppt yang menjadi faktor pembatas kehidupan plankton, terutama terdapat pada kawasan tambak di dekat laut dan jauh dari sungai. Rendahnya jumlah genus pada tambak tradisional juga dipengaruhi oleh tingkat kerusakan habitat plankton dan komoditas yang dibudidaya karena saat perluasan dan pembangunan tambak, tidak memperhatikan tata ruang dan tidak menyisakan tanaman bakau sebagai jalur hijau dan filter alami di sepanjang pantai, sungai, saluran utama dan di antara hamparan tambak. Menurut Pirzan dan Utojo (2010), pelestarian lingkungan pantai melalui penanaman bakau dapat memproteksi kondisi tambak dari abrasi, erosi, dan degradasi limbah.

Nilai indeks keragaman pada tambak intensif dan tradisional dalam studi ini masing-masing berkisar $1,26-2,38$ dan 0,10 - 1,97 pada Tabel 4 dan 5, dapat dinyatakan stabilitas komunitas plankton di tambak intensif bersifat moderat (sedang) yang berarti bahwa kualitas air tambak intensif relatif masih baik untuk mendukung perkembangan komunitas plankton, sedangkan pada tambak tradisional, komunitas planktonnya memiliki kondisi yang tidak stabil. Kondisi komunitas plankton yang tidak stabil dimaksudkan adalah komunitas bersangkutan sedang mengalami gangguan faktor lingkungan. Gangguan faktor lingkungan di tambak tersebut kemungkinan disebabkan oleh musim, pasang surut dan limbah tambak intensif. Menurut Basmi (2000), masuknya limbah ke perairan pantai juga menjadi faktor yang sangat berpengaruh dan dapat menimbulkan tekanan terhadap lingkungan perairan tambak. Dalam studi ini, nilai keragaman plankton pada tambak intensif relatif lebih tinggi dibandingkan dengan tambak tradisional, begitu juga di tambak tradisional di Kabupaten Banawa pada kisaran 0,23 - 1,58; Dolago pada kisaran 0,21 - 1,97 dan Malakosa pada kisaran 0,33 - 2,35 (Pirzan et al., 2006). Menurut Basmi (2000), apabila $H^{\prime}<1$ maka stabilitas komunitas biota dinyatakan tidak stabil, apabila nilai $\mathrm{H}^{\prime}$ berkisar dari 1 - 3 maka stabilitas komunitas biota adalah moderat (sedang) dan apabila nilai $\mathrm{H}^{\prime}>3$ berarti stabilitas komunitas biota bersangkutan dalam kondisi prima.

Nilai indeks keseragaman pada tambak intensif dan tradisional dalam studi ini masing- masing berkisar $0,10-1,5$ dan $0,08-1,0$ tertera pada Tabel 4 dan 5 . Nilai keseragaman pada tambak intensif dan tradisional secara rata-rata menunjukkan bahwa keseragaman genus relatif merata atau dengan kata lain jumlah individu pada masing-masing genus relatif sama, perbedaannya tidak menyolok (Basmi, 2000). Menurut Ali (1994), apabila nilai $\mathrm{E}>0,75$ maka termasuk nilai keseragamannya tinggi atau baik, sedangkan apabila nilai $\mathrm{E}<0,75$ maka nilai keseragamannya rendah.

Nilai indeks dominansi pada tambak intensif dan tambak tradisional dalam studi ini masing-masing berkisar 0,02-0,68 dan $0,01-0,75$ tertera pada Tabel 4 dan 5 , yang berarti bahwa dalam struktur komunitas plankton pada tambak intensif dan tradisional terdapat genus yang relatif mendominasi genus lainnya. Hal ini disebutkan oleh Basmi (2000) bahwa kisaran nilai indeks dominansi mulai dari 0-1, apabila nilai yang didapatkan mendekati nol berarti di dalam struktur komunitas biota 
yang diamati tidak terdapat genus yang secara ekstrim mendominasi genus lainnya.

Untuk menurunkan nilai indeks dominansi menjadi baik, dengan memperbaiki habitat pada kedua tambak yang telah mengalami degradasi, menerapkan penggunaan bakteri probiotik, kapur, padat tebar udang, pakan, pupuk organik dan anorganik serta pembasmi hama yang berimbang berdasarkan strandar operasional prosedur (SOP) sesuai dengan daya dukung lahan dan karakteristik lingkungan setempat. Hal ini sesuai dengan hasil pengamatan Pirzan et al. (2006) bahwa perairan tambak intensif dan tradisional di Kecamatan Lakawali, Kabupaten Luwu Timur memiliki indeks dominansi yang tinggi, masing-masing 0,66 dan 0,73, karena penggunaan antibiotik dan pupuk anorganik tidak seimbang serta konversi hutan bakau menjadi tambak kurang terkendali. Faktor utama yang mempengaruhi perubahan jumlah organisme, keragaman dan dominansi antara lain adanya perusakan habitat alami, pencemaran kimiawi dan perubahan iklim (Widodo, 1997).

\section{B. Kondisi perairan tambak}

Kunci utama peubah kualitas air sebagai media pendukung kehidupan di perairan tambak antara lain oksigen terlarut, suhu, salinitas dan $\mathrm{pH}$, sedangkan pendukung kehidupan lainnya, yaitu $\mathrm{NO}_{3}, \mathrm{NO}_{2}, \mathrm{NH}_{3}, \mathrm{PO}_{4}$, Fe, BOT dan TSS, ditampilkan pada Tabel 6.

Oksigen terlarut pada tambak intensif dan tradisional masing-masing berkisar 4,52 - 7,65 dan 3,76 - 9,20 (Tabel 6). Kisaran oksigen terlarut pada tambak intensif cukup stabil. Pemantauan mutu air dengan mengoperasionalkan kincir air dan pergantian air secara kontinyu dan teratur dapat menstabilkan oksigen terlarut artinya kebutuhan oksigen masih dapat dipenuhi menjelang pagi hari saat oksigen kritis bagi kehidupan udang termasuk di dalamnya plankton dan apabila oksigen terlarut dalam air mencapai titik jenuh (10 mg/L) akan dikeluarkan ke udara bebas melalui proses diffusi.

Tingginya oksigen terlarut pada tambak tradisional, sebagai hasil dari proses fotosintesis fitoplankton, kelekap dan lumut yang dilakukan saat siang hari. Persyaratan mutu air bagi tambak udang berkisar 3-10 $\mathrm{mg} / \mathrm{L}$ dan optimumnya berkisar $4-7 \mathrm{mg} / \mathrm{L}$ (Poernomo, 1988). Kandungan oksigen terlarut di perairan alami biasanya kurang dari $10 \mathrm{mg} / \mathrm{L}$ dan berfluktuasi secara harian dan musiman, tergantung pada pencampuran dan pergerakan massa air, aktivitas fotosintesis, respirasi dan limbah yang masuk ke badan air (Effendi, 2003).

Tabel 6. Peubah kualitas air tambak di Kabupaten Probolinggo, Provinsi Jawa Timur

\begin{tabular}{lcc}
\hline \multicolumn{1}{c}{ Peubah kualitas air } & \multicolumn{2}{c}{ Stasiun pengamatan } \\
\cline { 2 - 3 } & Tambak intensif & Tambak tradisional \\
\hline Oksigen terlarut $(\mathrm{mg} / \mathrm{L})$ & $4,52-7,65$ & $3,76-9,20$ \\
Suhu $\left({ }^{\circ} \mathrm{C}\right)$ & $27,1-30,3$ & $28,5-37,2$ \\
Salinitas $(\mathrm{ppt})$ & $15-30$ & $8-38$ \\
$\mathrm{pH}$ & $7,32-8,43$ & $7,17-8,98$ \\
$\mathrm{NO}_{3}(\mathrm{mg} / \mathrm{L})$ & $0,0685-0,1724$ & $0,0921-0,4956$ \\
$\mathrm{NO}_{2}(\mathrm{mg} / \mathrm{L})$ & $0,0046-0,0107$ & $0,0084-0,1349$ \\
$\mathrm{NH}_{3}(\mathrm{mg} / \mathrm{L})$ & $0,0181-0,0229$ & $0,3282-0,9719$ \\
$\mathrm{PO}_{4}(\mathrm{mg} / \mathrm{L})$ & $0,0193-0,0216$ & $0,1356-1,2206$ \\
$\mathrm{Fe}(\mathrm{mg} / \mathrm{L})$ & $0,0002-0,0059$ & $0,0008-0,0197$ \\
$\mathrm{BOT}(\mathrm{mg} / \mathrm{L})$ & $10,36-21,95$ & $45,33-67,17$ \\
$\mathrm{TSS}(\mathrm{mg} / \mathrm{L})$ & $7-54$ & $6-158$ \\
\end{tabular}


Suhu pada tambak intensif dan tambak tradisional masing-masing berkisar $27,1-30,3^{\circ} \mathrm{C}$ dan $28,5-37,2^{\circ} \mathrm{C}$ (Tabel 6). Suhu pada tambak intensif umumnya cukup stabil karena kedalaman airnya berkisar 1 2,5 m. Kondisi tambak intensif yang airnya lebih dalam, suhunya lebih stabil dibandingkan dengan tambak dangkal seperti pada umumnya tambak tradisional. Kisaran suhu pada tambak tradisional termasuk tinggi karena pelaksanaan studi ini dilakukan bertepatan dengan musim kemarau, juga dipacu dengan kondisi tambak umumnya dangkal. Menurut Simon (1988), pertumbuhan organisme akuatik utamanya plankton akan lebih baik pada tambak dengan kedalaman lebih dari $70 \mathrm{~cm}$ karena plankton terdiri dari organ hidup yang sangat dipengaruhi oleh kondisi sekelilingnya, sehingga pada kedalaman tersebut akan tercapai suhu yang sesuai dengan kebutuhan hidup bagi ikan, udang dan plankton. Menurut Poernomo (1992), persyaratan suhu air tambak udang berkisar $26-33^{\circ} \mathrm{C}$ dan kisaran optimumnya $29-$ $31^{\circ} \mathrm{C}$. Meningkatnya suhu air tambak seiring dengan meningkatnya konsumsi oksigen yang dibutuhkan oleh organisme akuatik termasuk plankton.

Kisaran salinitas pada tambak intensif yaitu $15-30$ ppt dan tradisional $8-38 \mathrm{ppt}$ (Tabel 6). Salinitas air tambak intensif selalu dipantau secara kontinyu dan teratur melalui percampuran air tawar dan laut serta dikondisikan selalu optimum bagi organism budidaya termasuk di dalamnya plankton. Kisaran salinitas yang rendah, didapatkan pada tambak tradisional yang jauh dari laut dan dekat dengan sungai, sebaliknya salinitas yang tinggi didapatkan pada tambak tradisional dipinggir laut dan jauh dari sungai dan juga dipacu oleh kondisi tambaknya yang dangkal akan mempercepat evaporasi dan berdampak meningkatkan salinitas. Menurut Poernomo (1992), kisaran salinitas air tambak udang yaitu 10-35 ppt dengan kisaran optimumnya 15-25 ppt.

Tingkat $\mathrm{pH}$ air tambak, biasanya tidak merupakan ancaman langsung bagi kelangsungan hidup organisme budidaya termasuk di dalamnya plankton karena jarang di dalam kolom air terdapat $\mathrm{pH}$ di atas nilai 9,0 atau di dalam sedimen dasar tambak, pH nya dibawah 6,0, kecuali di dalam tanah tambak yang bersifat masam,
$\mathrm{pH}$ nya sangat rendah yaitu dibawah 5,0. Nilai $\mathrm{pH}$ yang didapatkan pada tambak intensif dan tradisional umumnya netral hingga alkalis, masing-masing 7,32 - 8,43 dan 7,17 - 8,98 (Tabel 6). Kisaran nilai pH tambak tersebut tidak berpengaruh negatif terhadap organisme budidaya termasuk di dalamnya plankton atau masih layak sebagai media budidaya tambak. Menurut Poernomo (1992), tambak yang sudah lama beroperasi, umumnya $\mathrm{pH}$ air berkisar 7,5 8,7 , sedangkan tambak baru di kawasan mangrove yang belum di reklamasi, $\mathrm{pH}$ nya sangat rendah yaitu dibawah 5 . Nilai $\mathrm{pH}$ air optimum tambak udang berkisar 8,0 - 8,5. Pengaruh langsung pada $\mathrm{pH}$ rendah yaitu organisme budidaya selalu lembek karena tidak dapat membentuk kulit baru, sedangkan pada $\mathrm{pH}$ tinggi menyebabkan kadar ammonia bersifat toksik terhadap organisme tersebut.

Kandungan nitrat, nitrit dan fosfat yang tinggi kurang diperlukan untuk tambak intensif karena unsur $\mathrm{N}$ dan $\mathrm{P}$ yang tinggi dari sisa pakan merupakan sumber hara yang dapat menyebabkan blooming plankton dan berdampak pada terjadinya penurunan kualitas air, sedangkan nitrit itu sendiri sebagai produk dari proses nitrifikasi yang bersifat toksik terhadap organisme budidaya. Kandungan nitrat $\left(\mathrm{NO}_{3}-\mathrm{N}\right)$, nitrit $\left(\mathrm{NO}_{2}-\mathrm{N}\right)$, dan fosfat $\left(\mathrm{PO}_{4}-\mathrm{P}\right)$ yang didapatkan pada tambak intensif masing-masing 0,0685 - 0,1724 mg/L, 0,0046 - 0,0107 mg/L dan 0,0193 - 0,0216 $\mathrm{mg} / \mathrm{L}$, sedangkan pada tambak tradisional masing-masing 0,0921 0,4956 mg/L, 0,0084 - 0,1349 mg/L dan 0,1356 - 1,2206 mg/L (Tabel 6).

Kisaran masing-masing nilai tersebut masih layak sebagai media budidaya tambak. Menurut Effendi (2003), kandungan nitrat nitrogen yang lebih dari $0,2 \mathrm{mg} / \mathrm{L}$ dapat mengakibatkan terjadinya eutrofikasi perairan. Kandungan $\mathrm{NO}_{2}-\mathrm{N}$ air optimum tambak udang yaitu $0,25 \mathrm{mg} / \mathrm{L}$ (Poernomo, 1992). Kandungan $\mathrm{NO}_{2}-\mathrm{N}$ yang lebih dari $0,05 \mathrm{mg} / \mathrm{L}$ dapat bersifat toksik bagi sebagian besar organisme akuatik (Moore, 1991). Kandungan fosfat pada perairan alami berkisar 0,005 - 0,020 mg/L, sedangkan pada air tanah biasanya sekitar $0,02 \mathrm{mg} / \mathrm{L}$ dan jarang melebihi dari $1 \mathrm{mg} / \mathrm{L}$ (Boyd, 1988).Penambahan pupuk fosfat melalui pemupukan pada tambak tradisional di Kabupaten Luwu Utara, Mamuju dan Sinjai memperlihatkan adanya peningkatan 
jumlah plankton (Pirzan et al., 2003).

Kisaran nilai kadar amonia $\left(\mathrm{NH}_{3}\right)$ pada tambak intensif dan tradisional masingmasing 0,0181 - 0,0229 mg/L dan 0,3282 $0,9719 \mathrm{mg} / \mathrm{L}$ (Tabel 6), masih layak sebagai media budidaya tambak. Menurut Chamberlain (1988) bahwa amonia dalam air akan diubah menjadi nitrit oleh adanya aktivitas bakteri Nitrosomonas $\mathrm{sp}$ dan selanjutnya nitrit akan segera diubah menjadi nitrat oleh aktivitas bakteri Nitrobacter sp. Kondisi optimal untuk kedua proses tersebut terjadi apabila jumlah oksigen terlarut mencukupi, kapasitas buffer baik, pH netral dan suhu air rendah. Persyaratan kadar amonia total air tambak udang yaitu $1,0 \mathrm{mg} / \mathrm{L}$ dengan optimumnya $0,1 \mathrm{mg} / \mathrm{L}$ (Poernomo, 1992). Amonia dalam bentuk molekul $\left(\mathrm{NH}_{3}\right)$ lebih beracun dari pada dalam bentuk ion $\left(\mathrm{NH}_{4}+\right)$, daya racun amonia meningkat seiring dengan meningkatnya $\mathrm{pH}$, suhu dan salinitas dengan kesadahan air tambak yang rendah. Menurut Effendi (2003), sebagian besar biota akuatik termasuk di dalamnya plankton sensitif terhadap perubahan $\mathrm{pH}$ dan menyukai nilai $\mathrm{pH} 7-8,5$ serta pada $\mathrm{pH} 4,5-$ 5,5 dapat menghambat proses nitrifikasi.

Kandungan besi umumnya ditemukan pada perairan dengan kondisi anaerob dan dalam suasana asam. Besi termasuk unsur esensial bagi kehidupan tanaman air termasuk alga dan fitoplankton yang berperan sebagai penyusun sitokrom dan khlorofil. Besi juga dapat menjadi faktor pembatas bagi kehidupan organisme akuatik termasuk di dalamnya plankton, apabila kadarnya tinggi dan dalam suasana asam. Kisaran kandungan besi pada tambak intensif yaitu $0,0002-0,0059 \mathrm{mg} / \mathrm{L}$ dan tambak tradisional 0,0008 - 0,0197 mg/L (Tabel 6). Kisaran kadar besi di kedua tambak masih layak sebagai media budidaya tambak. Menurut Moore (1991), kadar besi $>1,0 \mathrm{mg} / \mathrm{L}$ dianggap membahayakan kehidupan organisme akuatik. Persyaratan kadar besi bagi budidaya tambak udang yaitu $0,03 \mathrm{mg} / \mathrm{L}$ dan optimumnya $0,01 \mathrm{mg} / \mathrm{L}$ (Poernomo, 1988).

Tingkat kesuburan perairan ditentukan oleh banyaknya kandungan bahan organik dan anorganik serta plankton yang keberadaannya melayang-layang di dalam air atau langsung mengendap ke dasar perairan tambak. Bahan organik pada tambak intensif berasal dari sisa pakan yang tidak termakan oleh udang dan kotoran udang, sedangkan pada tambak tradisional berasal dari aplikasi pupuk atau kotoran udang atau ikan. Bahan organik yang terlalu banyak menumpuk di dasar perairan tambak dapat mempengaruhi kehidupan organisme budidaya. Padatan tersuspensi yaitu padatan yang tidak lolos pada kertas saring ukuran $20 \mu \mathrm{m}$ atau tidak larut dalam air dan hanya melayang-layang dalam air.

Kandungan bahan organik total dan padatan tersuspensi total di tambak intensif yaitu10,36 - 21,95 mg/L dan 7- $54 \mathrm{mg} / \mathrm{L}$, sedangkan di tambak tradisional yaitu 45,33 - 67,17 mg/L dan 6 - $158 \mathrm{mg} / \mathrm{L}$ (Tabel 6). Kandungan bahan organik total pada tambak intensif yang didapatkan masih di bawah 26,0 mg/L tergolong kurang subur, sedangkan pada tambak tradisional tergolong subur. Kandungan bahan organik yang tinggi pada tambak intensif kurang bermanfaat, sedangkan pada tambak tradisional sangat diperlukan untuk perkembangan plankton sebagai pakan alami udang dan ikan. Menurut Reid (1961), perairan dengan kandungan bahan organik total di atas $26,0 \mathrm{mg} / \mathrm{L}$ adalah tergolong subur. Kisaran padatan tersuspensi pada kedua tambak dalam studi ini relatif lebih rendah dari pada yang didapatkan Utojo dan Pirzan (2009) dengan kisaran 4 - 180 mg/L. Kisaran nilai kandungan bahan organik dan padatan tersuspensi total yang didapatkan, masih dalam batas kategori baik dan mendukung kegiatan budidaya tambak.

\section{Simpulan}

Pada tambak intensif ditemukan sebanyak 23 genera plankton yang terdiri dari 16 genera fitoplankton yang tercakup ke dalam 3 kelas, yaitu Bacillariophyceae sebanyak 5 genera, Cyanophyceae 3 genera, Dinophyceae dan Clorophyceae, masing-masing 4 genera, sedangkan zooplankton terdiri dari 7 genera yang tercakup ke dalam 2 kelas yaitu Crustaceae sebanyak 6 genera dan Rotatoria 1 genus. Di tambak tradisional didapatkan sebanyak 13 genera yang terdiri dari 8 genera fitoplankton yang tercakup ke dalam Bacillariophyceae sebanyak 5 genera, Cyanophyceae 2 genera, dan Dinophyceae 3 genera, sedangkan zooplankton terdiri dari 
3 genera yang tercakup ke dalam kelas Crustaceae sebanyak 2 genera dan Rotatoria 1 genus.

Kelimpahan plankton di tambak intensif berkisar 702 - 4269 ind./L dan jumlah genus $6-14$ genera. Indeks keragaman 0,26 - 2,38, keseragaman 0,10 1,5, dan dominansi 0,02 -0,68. Di tambak tradisional memiliki kelimpahan plankton berkisar 134 - 776 ind./L dan jumlah genus 3 - 10 genera. Indeks keragaman 0,10 - 1,97, keseragaman $0,08-1,0$, dan dominansi 0,01 $-0,75$.

Kondisi perairan tambak intensif dan tradisional masih dalam batas yang dapat ditolerir oleh organisme budidaya.

Berdasarkan nilai indeks biologi, keragaman genus di tambak intensif relatif lebih tinggi dari pada tambak tradisional dan stabilitas komunitasnya moderat, sedangkan tambak tradisional tidak stabil. Secara rata-rata, keseragaman genus di kedua tambak tersebut relatif merata dan genus plankton mendominasi genus yang lain.

\section{Daftar Pustaka}

Anonim. 2012. Kabupaten Probolinggo Dalam Angka 2012. Kerjasama Badan Pusat Statistik Kabupaten Probolinggo dan Pemerintah Daerah Kabupaten Probolinggo, $332 \mathrm{hlm}$.

Amin, M. dan H.S. Suwoyo. 2012. Jenis dan Komposisi Plankton Pada Budidaya PolikulturUdang Windu, Udang Vaname, Ikan Bandeng dan Rumput laut di Tambak. Prosiding Forum Inovasi Teknologi Akuakultur 2011. Jilid 2. Pusat Penelitan dan Pengembangan Perikanan Budidaya Tahun 2011. Jakarta. Hal:773-778.

APHA (American Public Health Association) 1998. Standard methods for Examination of Water and Wastewater. Twentieth Edition. APHAAWWA-WEF, Washington, DC. 1015 p.

APHA (American Public Health Association) 2005. Standard methods for Examination of Water and Wastewater. Fourteenth Edition. APHA-AWWA-WPVC Published, American Public Health Association, 8001 Street, New York, p. 10-167.

Atmomarsono, M., Muliani, Nurbaya, Susianingsih, E., Nurhidayah dan
Rachmansyah. 2011. Petunjuk Teknis Aplikasi Bakteri Proboitik RICA pada Budidaya Udang Windu di Tambak.

Badan Penelitian dan Pengembangan Kelautan dan Perikanan, Pusat Penelitian dan Pengembangan Perikanan Budidaya, Balai Penelitian dan Pengembangan Budidaya Air Payau, Maros, $20 \mathrm{hlm}$.

Barnes, R.S.K., and K. Mann. 1991. Fundamental of Aquatic Ecosystem (Prologue). Blackwell Sci. Publisher Oxford, $226 \mathrm{p}$.

Basmi, H.J. 2000. Planktonologi : Plankton sebagai Bioindikator Kualitas Perairan. Fakultas Perikanan dan IImu Kelautan. Institut Pertanian Bogor (IPB), Bogor. 60 hal.

Botes, L. 2003. Phytoplankton Identification Catalogue.Globallast Monograph Series No. 7.Programme Coordination Unit Global Ballast Water Management Programme International Marine Organization. London. $77 \mathrm{p}$.

Boyd, C.F. 1990. Water quality in ponds for aquaculture. Auburn University, Alabama USA. 482 pp.

Chamberlain, W.G. 1988. Tinjauan kembali pengelolaan tambak udang, dalam Prinsip Pengelolaan Budidaya Udang.Technical Bulletin.Hal.48-64.

Effendi, H. 2003. Telaah Kualitas Air Bagi Pengelolaan Sumber daya dan Lingkungan Perairan. Kanisius (Anggota IKAPI), Yogyakarta, 258 pp.

Gracia, W.U., and R.U., Gracia. 1985. Prawn farming. Manila. $163 \mathrm{pp}$.

Haryadi, S., I.N.N. Suryodiputro dan B. Widigdo. 1992. Limnologi Penuntun Praktikum dan Metode Analisis Air. Fakultas Perikanan, Institut Pertanian Bogor, Bogor. 57 hal.

Klemeneie, A.K., Vrhovsek, D. and Smolar Z.N. 2007. Microplanktonic and microbenthic algal assemblages in the coastal brackish Lake Fiesa and the Dragonja Estuary (Slovenia) Nat. Croat. 16(1):63-78 pp.

Moore, J.W. 1991.Inorganic Contaminants of Surface Water.Springer-Verlag. New York. 334 pp.

Newell, G.E. and R.C. Newell. 1977. Marine Plankton. A Practical Guide 5 th. Edition Hutchinson of London. 244 p. 
Nontji, A. 2008.Plankton Laut. LIPI Press, Jakarta. 331 hal.

Odum, E.P. 1971. Fundamental of Ecology. Third Edition. W.B. Saunders, Company. Philadelphia. London, Toronto. $574 \mathrm{pp}$.

Pirzan, A.M., Gunarto and Utojo. 2003. Plankto diversity and relationship with phosphate in brackishwater pond of South Sulawesi. International Seminar on Marine and Fisheries.Agency for Marine and Fisheries Research.Ministry of Marine Affairs and Fisheries. Jakarta, p. 51-57.

Pirzan, A.M., Gunarto dan Utojo. 2006. Kelayakan dan kestabilan tambak dan sungai berdasarkan indikator diversitas plankton di Lakawali, Luwuk Timur, Sulawesi Selatan. Jurnal Torani. Fakultas Perikanan, Universitas Hasanuddin, Makassar. 16(3):153-161.

Pirzan, A.M. dan P. R. Pong-Masak. 2007. Hubungan produktivitas tambak dengan keragaman fitoplankton di Sulawesi Selatan. Jurnal Riset Akuakultur. Badan Riset Kelautan dan Perikanan, Pusat Riset Perikanan Budidaya, Jakarta, 2(2):211-220.

Pirzan, A.M. dan Utojo.2010. Keragaman Plankton dan Kondisi Lingkungan Perairan Kawasan Pertambakan Kabupaten Bone, Provinsi Sulawesi Selatan. Dalam Syamsuddin, S., Yuliati, H., Sipahutar, Safuridjal, Basit, A., S.Z., Suharto, Siregar, A.N., Rahardjo, S., Surya, R., dan Sanofa, V. (eds.). Prosiding Seminar Nasional Perikanan 2010.Pusat Penelitian dan Pengabdian Masyarakat (P3M). Sekolah Tinggi Perikanan, Jakarta. Hal.8-15.

Poernomo, A. 1988. Pembuatan Tambak Udang di Indonesia. Seri Pengembangan No. 7, 1988. Departemen Pertanian. Badan Penelitian dan Pengembangan Pertanian. Balai Penelitian Perikanan Budidaya Pantai, Maros. 30 hal.

Poernomo, A. 1992. Pemilihan Lokasi Tambak Udang Berwawasan Lingkungan. Seri Pengembangan

Hasil Penelitian No. PHP/KAN/ PATEK/004/1992. Badan Penelitian dan Pengembangan Pertanian, Pusat Penelitian dan Pengembangan
Perikanan bekerjasama dengan USAID/FRDP, Jakarta. 40 hal.

Setyobudiandi, I., Sulistiono, Yulianda, F., Kusuma, C., Hariyadi, S., Damar, A., Sembiring, A. dan Bahtiar. 2009. Sampling dan analisis data perikanan dan kelautan: terapan metode pengambilan contoh di wilayah pesisir dan laut Makaira, FPIK, IPB, Bogor. 313 hal.

Simon, C.M. 1988. Cara memonitor dan mengatur kualitas air pada tambak udang intensif. Dalam Prinsip Pengelolaan Budidaya Udang. Technical Bulletin. Hal.10-12.

Utojo dan A.M. Pirzan. 2009. Kondisi plankton di tambak bandeng dan garam Kabupaten Jeneponto, Sulawesi Selatan. Dalam Jumanto, Dwiyitno, Chasanah, Heruwati, E.S., Irianto, H.E., Saksono, H., Iwan Yusuf, B.L., Basmal, J., Murniati, Murwantoko, Probusunu,N., Rosmawaty, P., Rustadi dan Ustadi (eds.). Prosiding Seminar Nasional Tahun VI Hasil Penelitian Perikanan dan Kelautan Tahun 2009. Jurusan Perikanan dan Kelautan Fakultas Pertanian, Universitas Gadjah Mada, Yogyakarta. Hal.1-8.

Widodo, J. 1997. Biodiversitas sumberdaya perikanan laut peranannya dalam pengelolaan terpadu wilayah pantai. Dalam Mallawa, A., R. Syam, N. Naamin, S. Nurhakim, E.S. Kartamihardja, A. Poernomo, dan Rachmansyah (eds.). Prosiding Simposium Perikanan Indonesia II.Ujung Pandang 2-3 Desember 1997. Hal. 136-141.

Yamaji, I., 1976. Illustration of the marine plankton of Japan. Hoikusha Publishing Co. Ltd., Osaka, Japan, 369 pp. 
Lampiran 1. Jumlah genus dan individu plankton yang didapatkan pada tambak intensif di Kabupaten Probolinggo, Provinsi Jawa Timur

\begin{tabular}{|c|c|c|c|c|c|c|c|}
\hline \multirow[t]{2}{*}{ Jenis plankton } & \multicolumn{7}{|c|}{ Stasiun pengamatan $(\mathrm{St})$ tambak intensif } \\
\hline & St1 & St2 & St3 & St4 & St5 & St6 & St7 \\
\hline Fitoplankton & 14 & - & 10 & - & - & 17 & - \\
\hline Kelas Bacillariophyceae & - & 3025 & 76 & - & 720 & - & 58 \\
\hline 1. Melosira sp & 226 & 33 & - & - & - & 393 & - \\
\hline 2. Navicula $\mathrm{sp}$ & - & - & 175 & 182 & 66 & - & 200 \\
\hline 3. Nitzschia sp & 135 & - & 1014 & - & 802 & 85 & 154 \\
\hline \multicolumn{8}{|l|}{ 4. Pleurosigma sp } \\
\hline 5. Coscinodiscus sp & 2718 & - & - & - & - & - & 23 \\
\hline Kelas Cyanophyceae & - & - & 10 & 20 & - & 38 & - \\
\hline 6. Oscillatoria sp & - & 12 & 39 & - & - & 15 & - \\
\hline \multicolumn{8}{|l|}{ 7. Gleocapsa sp } \\
\hline 8. Merismopedia sp & 32 & - & - & - & 57 & - & 66 \\
\hline Kelas Chlorophyceae & 68 & - & 50 & - & 22 & - & - \\
\hline 9. Tetrastrum sp & 154 & - & 72 & - & - & 55 & 38 \\
\hline 10. Ceratium sp & - & - & 10 & 30 & - & - & - \\
\hline \multicolumn{8}{|l|}{ 11. Chaetoceros sp } \\
\hline 12. Thallosionema sp & 24 & - & - & - & 19 & - & 34 \\
\hline Kelas Dinophyceae & 23 & - & - & 10 & - & - & 12 \\
\hline 13. Prorocentrum sp & - & 15 & - & 25 & - & 45 & - \\
\hline 14. Gyrodinium sp & 36 & - & 57 & 90 & - & - & 20 \\
\hline \multicolumn{8}{|l|}{$\begin{array}{l}\text { 15. Protoperidinium } \mathrm{sp} \\
\text { 16. Signema } \mathrm{sp}\end{array}$} \\
\hline Zooplankton & 80 & - & - & 10 & - & - & 35 \\
\hline Kelas Crustaceae & 170 & - & - & 10 & - & 75 & 10 \\
\hline 17.Apocyclops sp & - & 44 & - & - & 25 & - & - \\
\hline 18.Copepoda sp & - & 87 & 20 & - & - & - & 10 \\
\hline 19. Tortanus sp & - & - & 77 & - & 40 & - & - \\
\hline 20. Acartia sp & 59 & - & - & 50 & - & 25 & 10 \\
\hline \multirow{4}{*}{\multicolumn{8}{|c|}{$\begin{array}{l}\text { 21. Oithona sp } \\
\text { 22. Temora sp } \\
\text { Kelas Rotatoria } \\
\text { 23. Brachionus sp }\end{array}$}} \\
\hline & & & & & & & \\
\hline & & & & & & & \\
\hline & & & & & & & \\
\hline Jumlah genus & 14 & 6 & 12 & 10 & 8 & 10 & 13 \\
\hline Jumlah individu (ind./L) & 4269 & 3216 & 1610 & 702 & 1029 & 3585 & 570 \\
\hline
\end{tabular}


Lampiran 2. Jumlah genus dan individu plankton yang didapatkan pada tambak tradisional di Kabupaten Probolinggo, Provinsi Jawa Timur

\begin{tabular}{|c|c|c|c|c|c|c|c|}
\hline \multirow{2}{*}{ Jenis plankton } & \multicolumn{7}{|c|}{ Stasiun pengamatan (St) tambak tradisional } \\
\hline & St1 & St2 & St3 & St4 & St5 & St6 & St7 \\
\hline Fitoplankton & & 251 & - & 68 & - & 154 & 57 \\
\hline Kelas Bacillariophyceae & - & 55 & - & - & 123 & - & 20 \\
\hline 1.Coscinodiscus sp & 38 & - & 35 & 95 & - & - & - \\
\hline 2. Gleotrichia sp & 66 & 214 & - & - & 255 & 98 & 25 \\
\hline 3. Navicula sp & - & - & 57 & - & - & - & 40 \\
\hline 4. Nitzschia sp & 30 & & & & & & \\
\hline 5.Pleurosigma sp & 22 & 49 & - & 20 & - & - & - \\
\hline Kelas Cyanophyceae & 415 & 10 & - & - & 310 & - & 136 \\
\hline 6. Gleocapsa sp & 38 & & & & & & \\
\hline 7.Oscillatoria sp & - & - & 42 & - & - & 45 & - \\
\hline Kelas Dinophyceae & 50 & 33 & - & 20 & - & - & - \\
\hline 8. Gyrodinium sp & 77 & - & - & 10 & - & - & 35 \\
\hline 9. Prorocentrum sp & 10 & & & & & & \\
\hline 10. Protoperidinium sp & 30 & & & & & & \\
\hline Zooplankton & & 16 & - & - & - & - & 17 \\
\hline Kelas Crustaceae & & - & - & - & - & 30 & 15 \\
\hline 11.Oithona sp & & & & & & & \\
\hline 12. Tortanus sp & & - & - & 25 & - & - & 50 \\
\hline Kelas Rotatoria & & & & & & & \\
\hline 13. Brachionus sp & & & & & & & \\
\hline Jumlah genus & 10 & 7 & 3 & 6 & 3 & 4 & 9 \\
\hline Jumlah individu (ind./L) & 776 & 628 & 134 & 238 & 688 & 327 & 395 \\
\hline
\end{tabular}

